\title{
Population and development in the Amazon: A longitudinal study of migrant settlers in the Northern Ecuadorian Amazon
}

\author{
Samuel SELLERS ${ }^{1,2^{*}}$, Richard BILSBORROW ${ }^{1,2,3}$, Victoria SALINAS ${ }^{4}$, Carlos MENA ${ }^{5}$ \\ ${ }_{1}$ University of North Carolina at Chapel Hill, Curriculum for the Environment and Ecology, Chapel Hill, NC USA \\ 2 University of North Carolina at Chapel Hill, Carolina Population Center, Chapel Hill, NC USA \\ ${ }^{3}$ University of North Carolina at Chapel Hill, Department of Biostatistics, Chapel Hill, NC USA \\ ${ }^{4}$ Universidade Federal de Minas Gerais, Centro de Desenvolvimento e Planejamento Regional -CEDEPLAR, Belo Horizonte, Brazil \\ ${ }^{5}$ Universidad San Francisco de Quito, Colegio de Ciencias Biológicas y Ambientales e Instituto de Geografía, Quito, Ecuador \\ *Corresponding author: samsellers@gmail.com
}

\begin{abstract}
This paper examines changes over time for a full generation of migrant settlers in the Northern Ecuadorian Amazon (NEA). Data were collected from a 2014 household survey covering a subsample of households surveyed previously in 1990 and 1999. We observed changes in demographic behavior, land use, forest cover, and living conditions. As the frontier develops, human fertility is continuing to decline with contraceptive prevalence rising. Meanwhile, out-migration from colonist households, largely to destinations within the region, persists. More households have secure land tenure than in 1999, and are better off as measured by possession of assets. There is continued growth in pasture, largely at the expense of forest. Farms still serve as an important livelihood source for families, though growing cities in the NEA are creating more non-agricultural economic opportunities. Our findings provide a snapshot of demographic, economic, land use, and livelihood changes occurring in the NEA during the past quarter century, providing useful information for policymakers seeking to balance economic and environmental goals in order to promote sustainable development as well as protect biodiversity.
\end{abstract}

KEYWORDS: family planning, deforestation, livelihoods, migration

\section{Población y desarrollo en la Amazonia: Un estudio longitudinal de colonos migrantes en la Amazonía norte del Ecuador}

\section{RESUMEN}

Este artículo describe cambios para una generación de migrantes en la Amazonía norte del Ecuador (ANE). Nosotros realizamos una encuesta en el 2014 de un subgrupo de fincas que encuestamos en 1990 y 1999. Observamos cambios demográficos, del uso de la tierra, de la cubierta forestal, y de las condiciones de vida de este grupo. Encontramos que la fecundidad está disminuyendo y que el uso de planificación familiar está aumentando. La migración fuera de las fincas continúa, la mayoría a destinos en la ANE. Más fincas tienen los derechos de su tierra y las familias tienen más bienes. Desde 1999 ha habido conversión en las fincas de bosques a pasto. Las fincas son fuentes importantes de sustento de vida, pero las ciudades en crecimiento están creando otras oportunidades económicas. Nuestros resultados demuestran cambios significativos demográficos, económicos, del uso de la tierra, y de las condiciones de vida durante el periodo 1990-2014. Nuestro artículo provee información útil para líderes que quieran avanzar metas económicas y ambientales para promover el desarrollo sostenible y proteger la biodiversidad.

PALABRAS CLAVE: planificación familiar, deforestación, sustento de vida, migración 


\section{INTRODUCTION}

The Northern Ecuadorian Amazon (NEA) is a critical biodiversity hotspot undergoing rapid change (Bass et al. 2010). Up until roughly 50 years ago, the region was largely uninhabited, aside from small indigenous populations. Since the discovery of oil in 1967, the region has received substantial human and financial inflows, the latter initially to build roads and pipelines to extract petroleum (Bilsborrow et al. 2004). The oil industry has grown, and is currently the major economic activity in the region. The industry accounts for large shares of foreign exchange earnings and government revenues, but is also a key source of pollution (Finer et al. 2008). Infrastructure developed to enable petroleum extraction has also facilitated human settlement deep in the NEA, opening up rainforest for agriculture. The growth of settlements in the NEA has coincided with changes in demographic, economic, land use, and livelihood choices, and has allowed for the exploration of various hypotheses concerning how population and resource interactions change over time in this forest frontier (Barbieri et al. 2005).

Forest frontiers around the world tend to have high human fertility rates (Carr 2004), which is also true in the NEA among indigenous inhabitants (Davis et al. 2015). The most recent analysis of human fertility among colonists (inmigrants from other parts of Ecuador) found substantially higher fertility rates in this population than in the rest of the country (Carr et al. 2006).

Households in frontier regions evolve over time through various stages, referred to as life cycles. These cycles reflect demographic and socioeconomic processes which have been theorized to be linked to changes in land use. Chayanov was one of the first to explore these patterns, positing that among peasant smallholders, household land use is a function of the dependency ratio of the household, whereby households with an abundance of labor relative to household size will adopt more labor-intensive agricultural practices, while households with less available labor relative to size will adopt less intensive practices (Chayanov 1986). However, it is possible that demographic changes may lead to the intensification of cultivation practices on existing land or to an expansion of agricultural activities onto marginal lands (Bilsborrow 1987). In the NEA, higher fertility is associated with land tenure insecurity and an increase in the amount of land devoted to pasture (Pan and López-Carr 2016). Household life cycle effects are seen as influencing land use decisions, especially in forest frontier settings like the NEA (Barbieri et al. 2005; Carr 2004).

Human migration in the NEA is a multilayered process, with individual, household, and community-level factors influencing migration decisions (Laurian et al. 1998). In particular, the story of migration in Ecuador's Amazon, as in many parts of the world, centers on individuals moving in order to improve their economic situation (Bilsborrow et al. 1987; DeJong and Gardner 1981; Gray and Bilsborrow 2013; López-Carr 2012). Demographic factors, such as age and gender, have been found to be strong predictors of migration in the NEA, with younger individuals (ages 12-34) and women more likely to migrate (Barbieri and Carr 2005). The effect of education on migration remains more ambiguous (Barbieri et al. 2009). Migration decisions also reflect individual and household life cycles_-many young people migrate to form new households, but are subsequently less likely to move again once settled (Caviglia-Harris et al. 2013).

Gender differences are pronounced in decisions about where to migrate. In the Amazonian context, when men migrate, they are more likely to go to other rural areas, often for manual agricultural work, whereas women are more likely to move to cities to pursue education or non-farm employment (Barbieri et al. 2009). The likelihood of migration has also been found to be positively related to distance from the nearest town, so those farther away are more likely to migrate. In contrast, those close to towns are more likely to maintain their residence and commute to urban jobs. Most of the out-migrants from colonist households observed in the 1990 and 1999 surveys remained within the NEA (Barbieri and Pan 2013).

Landholdings and land use often reflect the household life cycle stage and may also affect migration. Larger landholdings signify wealth, which could provide capital to facilitate outmigration (Bilsborrow 1987; Shaw 1974; VanWey et al. 2012). Conversely, larger landholdings provide greater opportunities for farm labor, which tends to reduce out-migration in search of other livelihoods (Gray 2009). This latter hypothesis appears dominant among colonists in the NEA, as larger plot sizes are associated with a lower propensity to out-migrate (Barbieri et al. 2009).

Farmers in the NEA use land in a variety of ways, including forest, pasture, annual and perennial crops, and fallow land (which generally regrows into secondary forest). Deforestation is pervasive throughout the NEA, and has largely been the result of smallholder farm expansion (Bilsborrow et al. 2004; Pichon 1997), although occasional transitions of farms away from cattle ranching can be a source of reforestation through secondary forest growth (Rudel et al. 2002). In general, farms in the region have fragmented, whereby parcels are subdivided and passed on to children or sold to third parties (Pan and Bilsborrow 2005). Consequently, data from the two previous survey rounds show that plot sizes have decreased, although an increase in more intensive forms of agriculture as a share of land use, such as from cattle to crops or from low-value crops such as corn and rice to higher value ones such as vegetables and fruit trees, has not materialized. Landholders with even a modest amount of land have often chosen instead to deforest in order 
to expand pasture (Bilsborrow et al. 2004). Research from the NEA and elsewhere in the Amazon suggests that possession of a land title is also linked to accelerated deforestation (Pan and Bilsborrow 2005; van Vliet et al. 2013).

Beyond household dynamics, it is clear that Protected Areas (PAs), such as national parks and patrimony forests, serve to promote the conservation of forests and native ecosystems, providing benefits to local communities (Naughton-Treves et al. 2005). In the NEA, PAs create different land management regimes that affect not only the area directly protected but also zones surrounding the PA (Mena et al. 2006). However, these effects are somewhat negated by large agroindustry complexes, such as African palm plantations, which promote tropical deforestation (Vijay et al. 2016) and in the NEA produce large-scale soil and water pollution (Castro $e t a l$. 2013; Mantilla 2012).

In this study we summarize key findings from the most recent round of a longitudinal household survey conducted in the NEA in 2014 and describe changes in the 15 years since the previous survey. Using our new household survey data, we explore human demographic, land use, and livelihood trends to follow up on earlier work that identified major changes between the first two rounds in 1990 and 1999 (Bilsborrow et al. 2004).

\section{MATERIALS AND METHODS}

To explore demographic, land use, and livelihood changes in the NEA, a longitudinal survey of farm plots owned by colonists was conducted in 1990 and 1999 (Bilsborrow et al. 2004) (Figure 1). The sample was selected for the 1990 survey, and was followed up in 1999. In 2014, a subsample of 1999 farm plots was resurveyed. Households in 1990 were selected through a two-stage sampling process. In the first stage, groups of farms called sectors were selected from a list (showing the number of farms per sector) provided by the Instituto Ecuatoriano de Reforma Agraria y Colonización. In the second stage, a cluster of contiguous farm plots (finca madres) of approximately 50 hectares were selected at random from each sample sector. Both sectors and the number of finca madres per sector were sampled using probabilities of selection proportional to estimated size (PPES). Earlier papers contain a more extensive discussion of the sampling procedures (Bilsborrow et al. 2004; Pichon 1997). The 1990 survey collected data from 418 farm households (found on 408 finca madres), while the 1999 study encountered 767 farm households plus 111 solares (small plots of less than 1 hectare)—reflecting a large increase due to land subdivision, resulting from both the formation of new farm households on existing farms through inheritance (allocations of land to sons and daughters reaching adulthood) and sales of portions of farms to in-migrants.

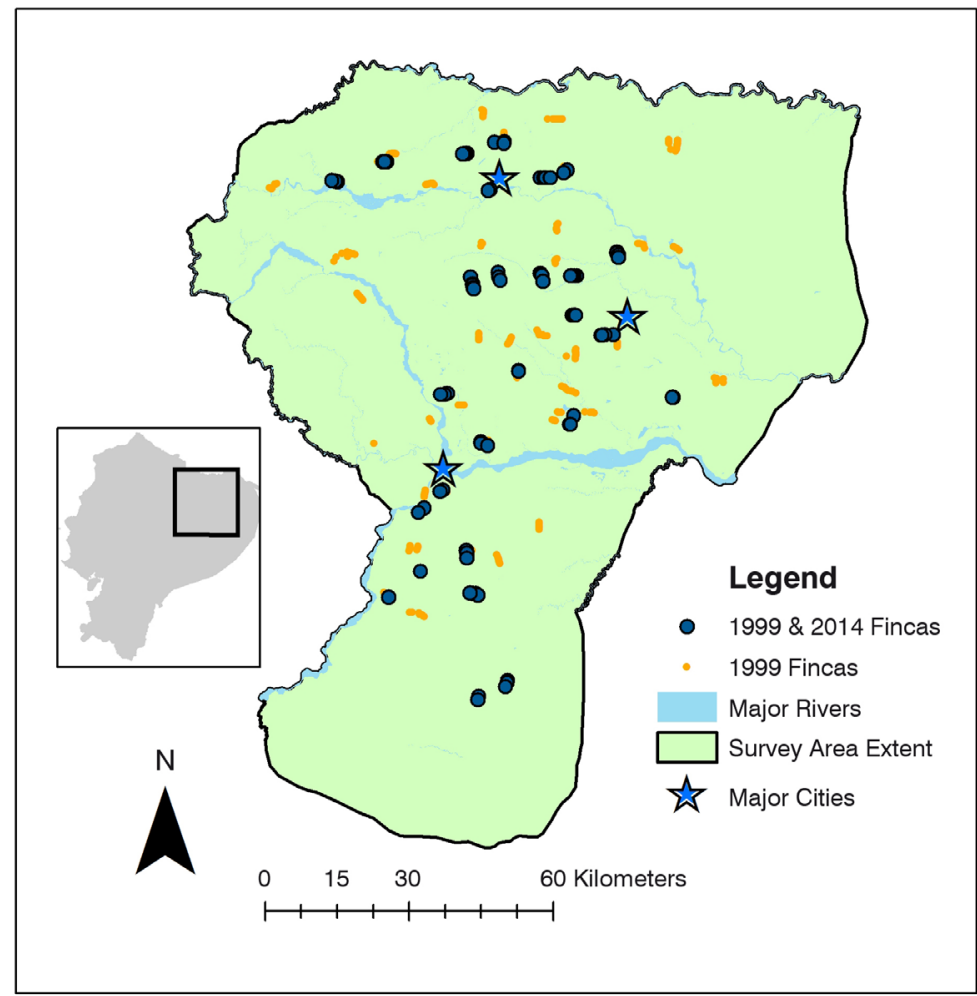

Figure 1. Map of the Northern Ecuadorian Amazon study region, showing its approximate location in northeastern Ecuador. This figure is in color in the electronic version. 
This paper introduces data from a new survey conducted in July-August 2014 on a subsample of the completed 392 finca madres (complete original farms of 40-50 ha allocated to the initial settlers in the region) that were surveyed in 1999. Due to funding constraints, we were unable to resample all of the original sample. We selected this subsample to yield a similarly geographically diverse sample while excluding some of the less accessible settlement sectors (farthest from the two main cities of Coca and Lago Agrio). This enabled the fieldwork to reach a larger number of sectors than would have otherwise been possible, albeit with a loss of some representativeness of the sample. Overall, 232 households were sampled from 100 finca madres, covering roughly a quarter of the original sample.

The three surveys cover a panel of finca madres and are hence longitudinal for land but not necessarily for households. If a farm owner in 1999 was no longer present in 2014, the new owner(s) and household members were surveyed. Thus, we did not track down heads of household who left. We also encountered cases where new subdivisions and consolidations occurred on a surveyed farm since 1999, and interviewed all new households that formed as a result of these changes. As with the two previous surveys, male and female heads of household were interviewed separately. Household heads (generally male) were asked about land use and tenure, agricultural activities, while the spouse of the head (generally female) was asked to complete a household roster, as well as provide information on housing quality and assets, fertility, and health. If one of the two was not present, the other member was asked to respond to both questionnaires. Due to errors in the field, some households provided only the head's questionnaire. In total, data were collected from 232 head surveys and 185 spouse surveys.

This remainder of the paper is divided into a series of short descriptive results sections as follows. Household and community demographics are explored first, followed by fertility and family planning, migration and remittance patterns, land tenure and living conditions, and land use. At the end, we briefly discuss caveats, future needs and provisional policy implications.

\section{RESULTS}

\section{Household and demographic changes}

As expected, settler populations in the NEA are changing, with increases in average age as well as decreases in mean household size. Between 1999 and 2014, the mean age for male and female heads of household interviewed increased by roughly six years for males (to a mean of 49) and seven years for females (to a mean of 44) (Table 1). The total dependency ratio fell from 0.87 in 1999 to 0.54 in 2014. A demographic maturation is also evident in the modest decline in the sex
Table 1. Household demographic characteristics in the Northern Ecuadorian Amazon surveyed in 1990, 1999 and 2014. Overall statistics are calculated based on entire survey population, excluding out-migrants after they left. Dependency ratio is calculated as proportion of population age 0-14 and 65+ divided by the population age 15-64. Sex ratio is calculated as the number of men divided by the number of women. Population share by age group is based on persons in farm households as well as solares. Highest level of education completed is calculated among individuals age 12 and above. Regarding household share by province, Orellana Province was created from a portion of Napo province in 1998, during the period of our study. As a result, the two provinces are considered a single area for the purposes of classifying households.

\begin{tabular}{lccc}
\hline & 1990 & 1999 & 2014 \\
\hline Total population size (persons) & 2761 & 4334 & 875 \\
\hline Overall demographic statistics & & & \\
Dependency ratio & 1.00 & 0.87 & 0.54 \\
Sex ratio & 1.21 & 1.17 & 1.15 \\
Average household size & 6.82 & 5.68 & 4.55 \\
Mean age (years) & & & \\
Head of household & 43.7 & 43.3 & 48.8 \\
Spouse of head & 38.7 & 37.4 & 44.0 \\
\hline Population share by age group (\%) & & & \\
0-12 & 40.3 & 38.4 & 23.7 \\
13-64 & 55.6 & 58.9 & 69.0 \\
65+ & 4.1 & 2.7 & 7.3 \\
\hline Birth origin of head (\%) & & & \\
Coast & 18.9 & 18.2 & 19.2 \\
\hline Highlands/Sierra & 72.7 & 68.0 & 59.3 \\
Amazon/Colombia & 8.4 & 12.2 & 21.5 \\
\hline Other country & 0.0 & 1.5 & 0.0 \\
\hline Highest level of education completed (\%) & & & \\
\hline Primary incomplete or below & 44.0 & 32.9 & 19.0 \\
\hline Primary complete & 41.1 & 41.1 & 27.2 \\
\hline Secondary incomplete & 11.3 & 20.3 & 25.5 \\
\hline Secondary complete or above & 3.6 & 5.6 & 28.3 \\
\hline Share of households by province (\%) & & & \\
\hline Napo/Orellana & 41.5 & 45.9 & 42.1 \\
\hline Sucumbios & 58.5 & 54.1 & 57.8 \\
\hline & & & \\
\hline
\end{tabular}

ratio from the more male-dominated population typical of early frontier settlement.

Roughly one generation has passed in the 24 years since the first survey in 1990. Since that time, the original children have had the opportunity to start their own households, with many choosing to remain in the Amazon. Thus, $21 \%$ of household heads were born in the Amazon, a substantial increase from previous surveys (Table 1). This was accompanied by a drop in the proportion of heads born in the Sierra, suggesting that in-migration from the Ecuadorian highlands has slowed. Household members are also increasingly well-educated$28 \%$ completed secondary school by 2014 , and only $19 \%$ 
had less than a primary school education, reflecting substantial improvements in educational attainment compared to the two previous surveys.

\section{Fertility and family planning}

Desires about future childbearing have remained roughly constant during the past quarter century (Table 2). When women of reproductive age were asked whether they would like to have another child, roughly one-in-four in each survey responded affirmatively, while around $70 \%$ said they wanted no more. This is somewhat surprising in light of the fact that the population of women of reproductive age is older in this survey than in previous studies, implying that they are more likely to be closer to completing their desired childbearing.

However, the use of family planning increased substantially since 1990 , from $35 \%$ to $63 \%$ in 2014 (Table 2). Among family planning users, modern methods are becoming more popular, notably injections rising from $4 \%$ to $26 \%$, while use

Table 2. Fertility and family planning use in households surveyed in the Northern Ecuadorian Amazon in 1990, 1999 and 2014. Samples for questions on desiring another child and currently using family planning reflect only female heads of household who are of reproductive age. The sample for the question on method of family planning includes only female heads of household who currently use family planning.

\begin{tabular}{lccc}
\hline & 1990 & 1999 & 2014 \\
\hline Desire another child (\%) & & & \\
Yes & 22.2 & 24.2 & 26.2 \\
No & 68.9 & 71.7 & 67.0 \\
\hline Uncertain & 8.9 & 4.1 & 6.8 \\
\hline Currently using FP (\%) & 34.8 & 44.4 & 63.1 \\
\hline Sample size (women) & 270 & 467 & 103 \\
\hline Method of family planning used (\%) & & & \\
\hline Pill & 21.3 & 24.6 & 16.9 \\
IUD & 12.8 & 5.3 & 0.0 \\
\hline Injection & 4.3 & 8.2 & 26.2 \\
\hline Female sterilization & 31.9 & 25.6 & 30.8 \\
\hline Rhythm method & 27.7 & 20.8 & 3.1 \\
\hline Other & 2.1 & 15.5 & 23.1 \\
Sample size (women) & 94 & 207 & 65 \\
\hline Children ever born, by age group & & & \\
\hline $12-14$ & 0.01 & 0.03 & 0.00 \\
\hline $15-19$ & 0.27 & 0.39 & 0.28 \\
\hline $20-24$ & 1.37 & 1.57 & 0.82 \\
\hline $25-29$ & 3.08 & 2.92 & 1.71 \\
\hline $30-34$ & 4.51 & 3.88 & 2.06 \\
\hline $35-39$ & 6.01 & 5.18 & 3.68 \\
\hline $40-44$ & 8.80 & 6.45 & 3.95 \\
\hline $45-49$ & 8.97 & 7.36 & 5.48 \\
\hline Sample size (women) & 636 & 1050 & 223 \\
\hline & & & \\
\hline & & & \\
\hline & & & \\
\hline
\end{tabular}

of the rhythm method fell from $28 \%$ to only $3 \%$ in 2014 . Still, the most widely used method in 2014, as in both the earlier surveys continued to be female sterilization at $31 \%$. Use of "other" methods, especially implants, rose rapidly.

Strong desires to avoid childbearing along with the substantial increase in family planning use has resulted in continuing fertility decline, with the reduction in children ever born particularly pronounced among younger cohorts. While our small sample does not allow us to calculate a reliable total fertility rate in 2014, a continuing decline among migrant settlers is evident from data on children ever born for the three survey years. Women who were ending their reproductive life cycles at the time of the 2014 survey (ages 45-49) had nearly two fewer children on average than similarly aged women in 1999.

\section{Migration and remittances}

Migration is an important demographic process in the NEA, involving internal population redistribution. Our results reflect so-called long-term or permanent migration, where individuals have left their farms to establish a residence in another location. In fact, only three of our 137 migrants in the study moved elsewhere for at least six months and then returned to their farm. Our survey questionnaire did not ask about short-term, seasonal or temporary migrants, only those moving to change their place of residence for at least six months. This study only documents permanent location changes and does not examine short-term movements to/from farms. For instance, individuals who live in urban areas may return to their farms of origin to help with crop harvesting on some weekends or holidays, a phenomenon we did not record.

While motivations for out-migrating from their settler farms in the NEA are multifaceted, there are several recurring patterns regarding gender, age, and education. As found in previous studies on migration in the NEA (Barbieri et al. 2009; Laurian et al. 1998), females continued to be more likely than males to migrate from their farm households, and comprised the majority of our migrant population ( $60 \%$ of out-migrants aged $12+$ were female), despite the fact that the comparablyaged survey population was $56 \%$ male (Table 3). Migrants also tended to be younger than non-migrants, the mean age of migrants was 24 , while it was 35 in the non-migrant population (among persons age 12 or above). Migrants also are better educated on average than non-migrants - $62 \%$ of migrants had greater than primary-level schooling compared to $47 \%$ of non-migrants.

Migration in the NEA continues to be highly gendered. While men and women shared three major motivations for migrating in our survey: employment, education, and accompanying a relative, these reasons differed by gender (Table 4). Males were more likely to migrate for employment, 
Table 3. Migrant vs. non-migrant descriptive statistics for households surveyed in the Northern Ecuadorian Amazon in 2014. Migrant statistics are presented for individuals age 12 and above at time of migration. Non-migrant statistics are presented only for individuals age 12 and above at the time of the median migration event, which took place in 2009. This is in order to facilitate more consistent comparison between migrants and non-migrants. Mean age and age groups for non-migrants reflect their ages as of 2009. Education values for non-migrants were measured at the time of the survey, whereas education values for migrants reflect attainment at time of migrant's departure.

\begin{tabular}{lcc}
\hline & Migrant & Non-migrant \\
\hline Female (\%) & 60.4 & 44.0 \\
Mean age (years) & 24.1 & 35.5 \\
Age groups (\%) & \\
$12-19$ & 38.8 & 25.3 \\
$20-34$ & 50.0 & 27.6 \\
$35+$ & 10.9 & 47.1 \\
Level of education (\%) & & \\
Primary incomplete or below & 6.0 & 21.9 \\
Primary complete & 32.1 & 31.5 \\
Secondary incomplete & 20.9 & 13.9 \\
Secondary complete or above & 41.0 & 32.7 \\
Sample size (persons) & 134 & 562 \\
\hline
\end{tabular}

Table 4. Migrant descriptive statistics for households surveyed in the Northern Ecuadorian Amazon in 2014. Statistics below are based on all migrants age 12 and above in surveyed households. Three return migrants are excluded from statistics. Median remittance totals include only migrants that sent remittances.

\begin{tabular}{lcc}
\hline & Males & Females \\
\hline Sex (\%) & 39.6 & 60.4 \\
\hline Mean age at departure & 26.7 & 22.4 \\
\hline Age at departure (\% by gender) & & \\
\hline $12-19$ & 20.8 & 50.6 \\
\hline $20-34$ & 60.4 & 43.2 \\
\hline $35+$ & 18.9 & 6.2 \\
\hline Migrant destinations (\%) & & \\
\hline Rural Amazon & 44.2 & 40.5 \\
\hline Urban Amazon & 32.7 & 27.8 \\
\hline Elsewhere & 23.1 & 31.6 \\
\hline Educational attainment (\%) & \\
\hline Primary incomplete or below & 1.9 & 8.6 \\
\hline Primary complete & 37.7 & 28.4 \\
\hline Secondary incomplete & 17.0 & 23.5 \\
\hline Secondary complete or above & 43.4 & 39.5 \\
\hline Main reason for departure (top 3 choices listed; \%) & \multicolumn{3}{|c}{} \\
\hline Accompany spouse/relative & 37.7 & 43.2 \\
\hline Employment & 45.3 & 23.5 \\
\hline Education & 3.8 & 21.0 \\
\hline Other & 13.2 & 12.3 \\
\hline Any remittances sent in past year (\%) & 35.8 & 24.7 \\
\hline Median remittance amount sent in past year (USD) & $\$ 2,500$ & $\$ 600$ \\
\hline & &
\end{tabular}

while females were more likely to migrate for education. Migration to accompany a spouse did not differ much by gender. Migrant demographics reflect these motivations. For instance, as women left to pursue education, they tended to leave at earlier ages than men; $51 \%$ of female migrants were age 12-19 at time of departure. However, we found no clear patterns with regard to education level and reason for departure. Overall, women were more likely than men to leave the Amazon (32\% versus 23\%), often to urban centers in Ecuador's Sierra. Within the Amazon, men were more likely to migrate to rural areas, largely for work.

The motivations migrants have for leaving are also reflected in data on sending remittances. Males were more likely to send remittances than females, in line with their being more likely than females to leave for employment. Moreover, males sent higher amounts, a median of $\$ 2,500$ USD per year, compared to $\$ 600$ per year for females (Table 4 ). We also asked respondent families whether they had sent any money to support outmigrants from their households, but only $12 \%$ said they had.

\section{Land tenure and living conditions}

Following changes in land tenure policies and procedures, the proportion of migrant settler households with secure land titles declined dramatically during the 1990s, but this process has reversed since 1999. As of 2014, 69\% of households possessed a formal land title (Table 5), doubling the proportion in 1999 while at the same time the proportion with no title fell by half from $48 \%$ to $24 \%$. In addition, asset ownership, an important indicator of household wealth, increased markedly since 1990 and 1999 (Figure 2). The vast majority of households now own a television $(76 \%)$, a radio $(66 \%)$, and a refrigerator (77\%).

Despite rapid economic growth in the region, including infrastructure such as roads and electricity networks, most rural homes still lack access to modern water and sanitation systems. Only $7 \%$ of sample households were attached to a sewer system - the remainder used latrines or had no system at all for disposing of human waste. By and large, households were unable to regularly access safe drinking water as the vast majority $(88 \%)$ found it at least sometimes necessary to boil and/or otherwise treat their water before drinking.

\section{Land use}

Two primary patterns of land use change, deforestation and farm fragmentation, continue to be pervasive. The 1999 survey found a strong trend towards smaller farm sizes due to subdivision, as well as reduced forest cover, which opened up a greater proportion of land for agriculture (Bilsborrow et al. 2004). These two trends have continued since. There has been a substantial reduction in mean farm size from 46.5 ha in 1990 to 25.3 ha in 1999 , and to 19.8 ha in 2014 , though the smaller and less isolated subsample in the 2014 survey 


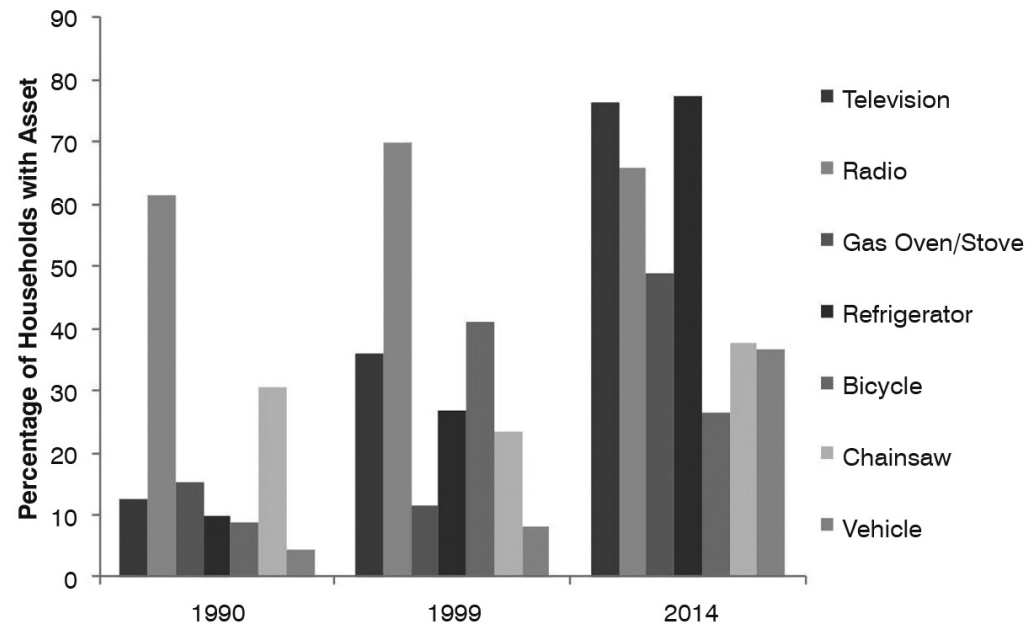

Figure 2. Possession of specific assets among surveyed households in the Northern Ecuadorian Amazon in 1990, 1999 and 2014.

Table 5. Land tenure arrangements by household surveyed in the Northern Ecuadorian Amazon in 1990, 1999 and 2014. N indicates sample size (number of households).

\begin{tabular}{lcccccc}
\hline & \multicolumn{2}{c}{1990} & \multicolumn{2}{c}{1999} & & 2014 \\
\hline Document type & $\mathrm{N}$ & $\%$ & $\mathrm{~N}$ & $\%$ & $\mathrm{~N}$ & $\%$ \\
\hline Full title & 208 & 50.2 & 262 & 34.2 & 122 & 68.9 \\
\hline Certificate of possession/provisional title & 179 & 43.2 & 97 & 12.7 & 4 & 2.3 \\
\hline Surveyed only & - & & 42 & 5.5 & 8 & 4.5 \\
No title or claim & 27 & 6.5 & 365 & 47.7 & 43 & 24.3 \\
\hline Total plots & 414 & & 766 & & 177 & \\
\hline
\end{tabular}

may account for part of the most recent drop (Table 6). ${ }^{1}$ In $2014,45 \%$ of farms were $1-10$ ha, while the proportion of plots $>50$ ha fell to under $10 \%$. The survey did not inquire about land use on plots smaller than 1 ha.

Overall, plot size is linked to land use choices. Annual and perennial crops, which are more intensive forms of land use than cattle raising, account for a higher proportion of land area on smaller plots, providing evidence of intensification as a response to land scarcity. Larger plots had greater proportions of land in both pasture and forest cover, and unsurprisingly, were more likely to have cattle present and more cattle on the farm.

Land use trends observed between 1990 and 1999 largely continued to 2014 (Figure 3). Since 1999, forest cover has

\footnotetext{
Due to data coding errors, in 23 households the sum of land areas assigned to each use (crops, pasture, forest, etc.) did not match the total area of land that the household reported owning in a different section of the questionnaire. To address these discrepancies, we assumed data regarding specific uses is likely to be more precise than the overall plot total. In these cases, we adopted one of two responses depending on the direction of the error. For households that had a greater area of land allocated to different uses than the total reported, the total area of land owned was adjusted to equal the sum of land areas allocated by use. Households that reported less land ( $>2$ ha difference) allocated to different uses than was reported in the total were dropped from the analysis since we could not know how to impute the difference to specific uses. These adjustments left us with 180 farms used in the analysis reported here.
}

continued to decline, although deforestation of new areas decreased. In 1990, roughly $60 \%$ of total land in sample farms was primary forest, which rapidly fell to $45 \%$ in 1999 . By 2014 , primary forest cover fell to $28 \%$ on the survey farms, implying a slower annual absolute loss of forest cover, although with similar rates of forest loss in both time periods. This slowdown in forest loss is in line with other estimates of forest change in the NEA over a similar time period (Holland et al. 2014).

Primary forest is being replaced with two other land cover types: pasture and secondary forest. Pasture has grown, from $20 \%$ in 1999 to $33 \%$ of sample farm land in 2014 (Figure $3)$. Two out of every five (41\%) households owned cattle, highlighting the demand for pasture and the importance of livestock rearing as a livelihood strategy. Additionally, on larger farms, more land is being left fallow, resulting in secondary forest growth, from around $11 \%$ of total farm area in 1999 to $21 \%$ by 2014 . Land devoted to crops has stayed relatively stable between the three surveys, at roughly $15-20 \%$ of land cover. Within cropland, the share devoted to annual versus perennial crops has also not changed substantially. 


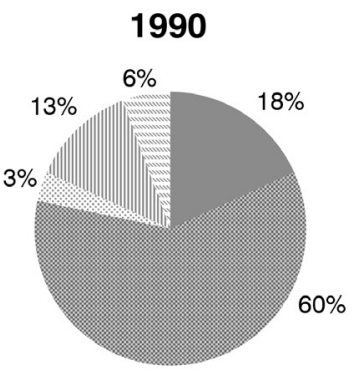

1999

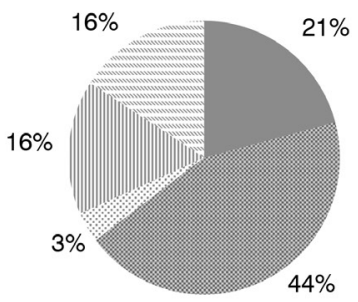

2014

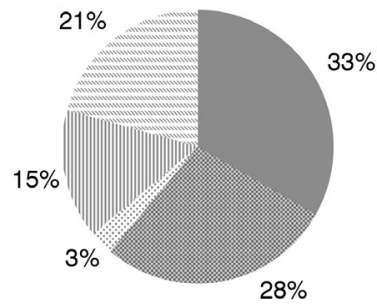

- Pasture : : Primary Forest Annuals III! Perennials : Fallow/Other

Figure 3. Share of land use among surveyed households in the Northern Ecuadorian Amazon in 1990, 1999 and 2014.

Table 6. Share of land use by overall plot size in households surveyed in the Northern Ecuadorian Amazon in 2014. Land use values are indicated in Ha and percentage of property area.

\begin{tabular}{|c|c|c|c|c|c|c|c|c|c|c|c|c|c|c|c|}
\hline \multirow{3}{*}{$\begin{array}{l}\text { Plot size } \\
\text { category }\end{array}$} & \multirow{3}{*}{ N plots } & \multirow{3}{*}{$\begin{array}{c}\text { Share of } \\
\text { survey plots }\end{array}$} & \multirow{3}{*}{$\begin{array}{c}\begin{array}{c}\text { Mean } \\
\text { plot size }\end{array} \\
\mathrm{Ha}\end{array}$} & \multicolumn{10}{|c|}{ Land use type } & \multicolumn{2}{|c|}{ Cattle ownership } \\
\hline & & & & \multicolumn{2}{|c|}{ Annuals ${ }^{\mathrm{a}}$} & \multicolumn{2}{|c|}{ Perennials ${ }^{b}$} & \multicolumn{2}{|c|}{ Pasture } & \multicolumn{2}{|c|}{ Primary forest } & \multicolumn{2}{|c|}{ Fallow/other ${ }^{c}$} & \multirow{2}{*}{$\begin{array}{c}\begin{array}{c}\text { Own } \\
\text { cattle }\end{array} \\
\%\end{array}$} & \multirow[t]{2}{*}{$\begin{array}{l}\text { Mean N } \\
\text { cattle }^{\mathrm{d}}\end{array}$} \\
\hline & & & & $\mathrm{Ha}$ & $\%$ & $\mathrm{Ha}$ & $\%$ & $\mathrm{Ha}$ & $\%$ & $\mathrm{Ha}$ & $\%$ & $\mathrm{Ha}$ & $\%$ & & \\
\hline $1-4.9$ & 47 & 26.1 & 2.7 & 0.3 & 9.8 & 0.9 & 33.3 & 0.7 & 25.3 & 0.4 & 14.4 & 0.5 & 17.1 & 21.3 & 3.0 \\
\hline $5-9.9$ & 34 & 18.9 & 6.8 & 0.4 & 6.1 & 2.7 & 40.0 & 1.3 & 19.6 & 0.8 & 11.5 & 1.5 & 22.8 & 17.6 & 3.2 \\
\hline $10-19.9$ & 25 & 13.9 & 12.6 & 0.4 & 3.1 & 2.7 & 21.2 & 4.6 & 36.9 & 2.1 & 16.6 & 2.8 & 22.2 & 44.0 & 4.4 \\
\hline $20-29.9$ & 24 & 13.3 & 24.3 & 1.6 & 6.6 & 3.1 & 12.9 & 9.0 & 37.1 & 3.6 & 14.8 & 7.0 & 28.7 & 62.5 & 4.6 \\
\hline $30-49.9$ & 33 & 18.3 & 41.5 & 0.3 & 0.8 & 4.3 & 10.3 & 16.4 & 39.5 & 13.8 & 33.3 & 6.7 & 16.1 & 72.7 & 7.8 \\
\hline$>50$ & 17 & 9.4 & 55.9 & 0.6 & 1.1 & 7.7 & 13.8 & 13.6 & 24.3 & 21.6 & 38.6 & 12.4 & 22.2 & 47.1 & 7.1 \\
\hline Average/total & 180 & 100 & 19.8 & 0.5 & 2.7 & 3.0 & 15.3 & 6.6 & 33.1 & 5.6 & 28.2 & 4.1 & 20.8 & 41.1 & 5.5 \\
\hline
\end{tabular}

a. Annual crops include rice, maize, yucca, and bananas.

b. Perennial crops include coffee, cacao, African palm, palmito, naranjilla, and sugar cane.

c. Fallow/other category includes secondary forest, "other" forest, land marked as fallow, and swamp.

d. Among households that own cattle on surveyed farms.

\section{DISCUSSION}

As development in the NEA continues, the region is beginning to resemble the rest of the country as measured by demographic and economic behavior. Fewer babies are being born, more migration to urban areas is occurring, farm plots are becoming smaller, and households are growing modestly wealthier. In addition, secure land tenure is becoming more widespread. These developments are largely positive for colonists, many of whom moved to the Amazon in order to seek better lives beginning in the 1970s and continuing albeit at a slower pace.

Demographic changes in the region reflect the effects of the 1999 population aging and passing through its life cycle over 15 years, with the increase in mean age of 6-7 years reflecting the countervailing effect of some of the children becoming household heads as they are allocated parts of the original finca madre plots, plus some continuing in-migrant families taking over plots from the aging 1999 heads. Such aging results in a changing overall age structure, with a sharp drop in the share of young people and an increase in the share of the working adult-age population.

Regarding fertility and family planning, we note that use of modern family planning methods including injectables, implants and sterilization grew, suggesting that family planning services are increasingly available and affordable in the NEA. The increase in contraceptive use, along with constant desires about childbearing suggest that the unmet need for family planning services has fallen considerably for colonist women in the NEA during the past 24 years. These trends are also confirmed by the fall in children ever born. Collectively, these trends suggest that women are often beginning childbearing later. Thus, downward trends in fertility observed in the early 1990s appear to have continued into the 21 st century.

Additionally, living standards in this region are improving, though vary widely between households. Remittances are being driven largely by a small proportion of male migrants. This is due to the fact that more male than female migrants 
in our sample are likely to be employed in general, and in particular by petroleum companies, which often pay higher wages than other employers. Moreover, data on asset ownership show significant gains in wealth accumulation. However, some of this apparent increase might be due to the 2014 sample being a bit less dispersed than the earlier samples (i.e., closer to urban centers).

While the quality of life for colonists has improved in many ways since 1999 , the same cannot be said for forests. Our survey confirms that despite recent slowdowns in forest loss, the NEA overall continues to experience a high deforestation rate as forest is being converted into pasture. Previous studies exploring cattle ownership in the Amazon associated possession and number of livestock with household wealth, suggesting that cattle will continue to proliferate as the region becomes more affluent (Caviglia-Harris 2005; Murphy et al. 1997). Unless the Ecuadorian government develops stronger policies to protect forests, this valuable ecosystem is likely to continue to be further degraded. Nevertheless, some of our findings have positive implications for forest health, including broad declines in fertility and continuing ruralurban migration, which are likely to reduce human pressures on the environment.

In the NEA, household livelihood dynamics are strongly affected by exogenous factors, such as the price of oil and the level of government investment in social development projects. While our article centers on household changes across time, many of these changes are partly the result of government policy choices to promote development in the NEA, including expanded access to education and health services. However, adverse impacts of other development policies to promote forest resource extraction are also felt within and among households, such as on women's health (San Sebastián et al. 2002), deforestation and biodiversity loss (Castro et al. 2013), and human rights violations (Latorre et al. 2015). Policy choices, such as the use of payments for environmental services (PES) to discourage land clearing, may also help change land use trajectories, although the use of PES in the NEA remains in its infancy and it is too early to tell whether these efforts will be successful in preventing forest cover loss (De Koning et al. 2011). Other policies to increase local action by households and communities to monitor and reconstruct their environment should be developed.

\section{CONCLUSIONS}

The results of this quarter-century retrospective illustrate that livelihood patterns for NEA settlers are diversifying as the region continues to change demographically, economically, and environmentally. Future larger-scale surveys of settler households are likely to record populations that are increasingly older, urban, and mobile and who are less likely to rely on traditional agricultural activities, particularly growing crops, for their livelihoods. How the government and local communities respond to the recent fall in the price of oil, which has reduced financing for social development projects and left people with fewer work opportunities, will be crucial to determining future demographic, economic, and environmental trends in the region. Future studies should seek to understand how policy choices interact with household demographic, migration, and land use decisions in the NEA, particularly as the region continues to become more economically diversified and less reliant on agriculture. Given the importance of the Ecuadorian Amazon landscape as a provider of livelihood opportunities as well as critical ecosystem services, policymakers must work to strike a careful balance between development to accommodate growing and shifting populations in the region as well as the need to ensure remaining forests are sufficiently protected from agricultural and extractive activities.

\section{ACKNOWLEDGEMENTS}

This research received support from the USAID Initiative for Conservation in the Andean Amazon (ICAA), the Land Use, Climate, and Infections in Western Amazonia project (CRNIII 3036) funded by the IAI-The Inter-American Institute for Global Change Research, the Population Research Training (T32 HD007168) and the Population Research Infrastructure Program (P2C HD050924) grants awarded to the Carolina Population Center at the University of North Carolina at Chapel Hill by the Eunice Kennedy Shriver National Institute of Child Health and Human Development. We thank Universidad San Francisco de Quito for providing space for training and data collection supplies, as well as to Eduardo Arguello, Lourdes Ruiz, and our 12 excellent interviewers for facilitating this project.

\section{REFERENCES}

Barbieri, A.F.; Bilsborrow, R.E.; Pan, W.K. 2005. Farm household lifecycles and land use in the Ecuadorian Amazon. Population and Environment, 27: 1-27.

Barbieri, A.F.; Carr, D.L. 2005. Gender-specific out-migration, deforestation and urbanization in the Ecuadorian Amazon. Global and Planetary Change, 47: 99-110.

Barbieri, A.F.; Carr, D.L.; Bilsborrow, R.E. 2009. Migration within the frontier: the second generation colonization in the Ecuadorian Amazon. Population Research and Policy Review, 28: 291-320.

Bass, M.S.; Finer, M.; Jenkins, C.N.; Kreft, H.; Cisneros-Heredia, D.F.; McCracken, S.F., et. al. 2010. Global conservation significance of Ecuador's Yasuní National Park. PLoS ONE, 5: e8767. 
Bilsborrow, R.E. 1987. Population pressures and agricultural development in developing countries: A conceptual framework and recent evidence. World Development, 15: 183-203.

Bilsborrow, R.E.; Barbieri, A.F.; Pan, W.K. 2004. Changes in population and land use over time in the Ecuadorian Amazon. Acta Amazonica, 34: 635-647.

Bilsborrow, R.E.; McDevitt, T.M., Kossoudji, S.; Fuller, R. 1987. The impact of origin community characteristics on rural-urban outmigration in a developing country. Demography, 24: 191-210.

Carr, D.L. 2004. Proximate population factors and deforestation in tropical agricultural frontiers. Population and Environment, 25: 585-612.

Carr, D.L.; Pan, W.K.; Bilsborrow, R.E. 2006. Declining fertility on the frontier: the Ecuadorian Amazon. Population and Environment, 28: 17-39.

Castro, M.; Sierra, R.; Calva, O.; Camacho, J.; Lopez, F. 2013. Zonas de procesos homogéneos de deforestación del Ecuador: factores promotores y tendencias al 2020. Programa GESOREN-GIZ y Ministerio de Ambiente del Ecuador, Quito, Ecuador. 173p.

Caviglia-Harris, J. L. 2005. Cattle accumulation and land use intensification by households in the Brazilian Amazon. Agricultural and Resource Economics Review, 34: 145-162.

Caviglia-Harris, J.L.; Sills, E.; Mullan, K. 2013. Migration and mobility on the Amazon frontier. Population and Environment, 34: 338-369.

Chayanov, A.V. 1986. The Theory of Peasant Economy. University of Wisconsin Press, Madison, WI, 316p.

Davis, J.; Bilsborrow, R.E.; Gray, C.L. 2015. Delayed fertility transition among indigenous women in the Ecuadorian Amazon. International Perspectives on Sexual and Reproductive Health, 41: 1-10.

De Koning, F.; Aguiñaga, M.; Bravo, M.; Chiu, M.; Lascano, M.; Lozada, T.; Suarez, L. 2011. Bridging the gap between forest conservation and poverty alleviation: the Ecuadorian Socio Bosque program. Environmental Science \& Policy, 14: 531-542.

DeJong, G.F.; Gardner, R.W. 1981. Introduction. In: DeJong, G.F.; Gardner, R.W. (Ed.). Migration Decision Making: Multidisciplinary Approaches to Microlevel Studies in Developed and Developing Countries. Pergamon Press, Elmsford, NY, p.1-10.

Finer, M.; Jenkins, C.N.; Pimm, S.L.; Keane, B.; Ross, C. 2008. Oil and gas projects in the western Amazon: threats to wilderness, biodiversity, and indigenous peoples. PloS ONE, 3: e2932.

Gray, C.L. 2009. Environment, land, and rural out-migration in the southern Ecuadorian Andes. World Development, 37: 457-468.

Gray, C.L.; Bilsborrow, R.E. 2013. Environmental influences on human migration in rural Ecuador. Demography, 50: 1217-1241.

Holland, M. B.; de Koning, F.; Morales, M.; Naughton-Treves, L.; Robinson, B.E.; Suárez, L. 2014. Complex tenure and deforestation: Implications for conservation incentives in the Ecuadorian Amazon. World Development, 55: 21-36.

Latorre, S.; Farrell, K.N.; Martínez-Alier, J. 2015. The commodification of nature and socio-environmental resistance in Ecuador: An inventory of accumulation by dispossession cases, 1980-2013. Ecological Economics, 116: 58-69.
Laurian, L.; Bilsborrow, R.E.; Murphy, L. 1998. Migration decisions among settler families in the Ecuadorian Amazon: the second generation. Research in Rural Sociology and Development, 7: $169-185$.

López-Carr, D. 2012. Agro-ecological drivers of rural out-migration to the Maya Biosphere Reserve, Guatemala. Environmental Research Letters, 7: 45603.

Mantilla, M.J.A. 2012. Análisis de la huella de carbono y del crecimiento del cultivo de la palma africana en el Ecuador. Colegio de Ciencias Biológicas y Ambientales, Universidad San Francisco de Quito, Cumbaya, Ecuador, 104p.

Mena, C.F.; Barbieri, A.F.; Walsh, S.J.; Erlien, C.M.; Holt, F.L.; Bilsborrow, R.E. 2006. Pressure on the Cuyabeno Wildlife Reserve: development and land use/cover change in the Northern Ecuadorian Amazon. World Development, 34: 1831-1849.

Murphy, L.; Bilsborrow, R.E.; Pichon, F. 1997. Poverty and prosperity among migrant settlers in the Amazon rainforest frontier of Ecuador. Journal of Development Studies, 34: 35-65.

Naughton-Treves, L.; Holland, M.B.; Brandon, K. 2005. The role of protected areas in conserving biodiversity and sustaining local livelihoods. Annual Review of Environment and Resources, 30: 219-252.

Pan, W.K.; Bilsborrow, R.E. 2005. The use of a multilevel statistical model to analyze factors influencing land use: a study of the Ecuadorian Amazon. Global and Planetary Change, 47: 232-252.

Pan, W.K.; López-Carr, D.L. 2016. Land use as a mediating factor of fertility in the Amazon. Population and Environment, 38: 21-46.

Pichon, F.J. 1997. Colonist land-allocation decisions, land use, and deforestation in the Ecuadorian Amazon frontier. Economic Development and Cultural Change, 45: 707-744.

Rudel, T.K.; Bates, D.; Machinguiashi, R. 2002. A tropical forest transition? Agricultural change, out-migration, and secondary forests in the Ecuadorian Amazon. Annals of the Association of American Geographers, 92: 87-102.

San Sebastián, M.; Armstrong, B.; Stephens, C. 2002. Outcomes of pregnancy among women living in the proximity of oil fields in the Amazon Basin of Ecuador. International Journal of Occupational and Environmental Health, 8: 312-319.

Shaw, R.P. 1974. Land tenure and the rural exodus in Latin America. Economic Development and Cultural Change, 23: 123-132.

van Vliet, N.; Adams, C.; Vieira, I.C.G.; Mertz, O. 2013. "Slash and burn" and "shifting" cultivation systems in forest agriculture frontiers from the Brazilian Amazon. Society \& Natural Resources, 26: $1454-1467$.

VanWey, L.K.; Guedes, G.R.; D’Antona, Á.O. 2012. Out-migration and land-use change in agricultural frontiers: insights from Altamira settlement project. Population and Environment, 34: 44-68.

Vijay, V.; Pimm, S.L.; Jenkins, C.N.; Smith, S.J. 2016. The impacts of oil palm on recent deforestation and biodiversity loss. PLoS ONE, 11: e0159668.

Received: 29/11/2016

Accepted: 25/08/2017 